\title{
SPECIES DIVERSITY OF ODONATA IN THE SELECTED PROVENANCES OF SANDAL IN SOUTHERN INDIA
}

\section{Gaurav Sharma ${ }^{1}$, R. Sundararaj ${ }^{2}$ and L.R. Karibasvaraja ${ }^{3}$}

1,2,3 Wood Biodegradation Division, Institute of Wood Science and Technology, $18^{\text {th }}$ Cross, Malleswaram, Bangalore, Karnataka 560003, India

E-mail: ${ }^{1}$ gaurav@pandit2@rediffmail.com; ${ }^{2}$ rsundar@iwst.res.in (corresponding author)

The insect order Odonata includes some of the most ancient and beautiful insects that ever roamed earth. It also includes some of the largest flying invertebrates ever to have lived. Approximately 6,000 species and subspecies belonging to 630 genera in 28 families are known from all over the world (Tsuda, 1991), out of which 499 species and subspecies of Odonata under 139 genera in 17 families, are represented in India (Prasad \& Varshney, 1995). They are among the dominant invertebrate predators in any ecosystem. Being predators both at larval and adult stages, they play a significant role in the food chain of forest ecosystem (Vashishth et al., 2002). In addition, their value as indicators of quality of the biotope is being increasingly recognized (Subramanian, 2002). A perusal of literature revealed that no consolidated account is available on the Odonata fauna of sandal ecosystem, which is charactierised by the mixed vegetation dominated by sandal plants, though Prasad (1987) reported 38 species of Odonata from southern India. Gunathilagaraj et al. (1999) recorded 16 species of Odonata in rice fields of Coimbatore. Kandibane et al. (2005) recorded 12 species of Odonata in an irrigated rice field of Madurai, Tamil Nadu. Emiliyamma (2005) recorded 31 species from the Kottayam district and Emiliyamma et al. (2005) reported 137 species of odonates from Kerala. In the present study an attempt has been made to enlist the odonates found in the six selected provenances of sandal in southern India.

Materials and Methods: The surveys were conducted in the six selected sandal provenances of India during 2004-05 to study the diversity of Odonata -- Bengaluru, Thangli and Mandagadde in Karnataka, Javadis and Chitteri in Tamil Nadu and Marayoor in Kerala. The details of the study area are given in Table 1. The odonate collections were made two times in a year (postmonsoon and presummer seasons) by using sweep nets. All the collected adult specimens were pinned and provided with proper locality and collection data. The specimens were identified with the help of keys provided by Fraser (1933, 1934, 1936).

Quantitative estimation of species and individuals in different provenances was made using data from survey. Species diversity $\left(\mathrm{H}^{\prime}\right)$ was computed based on Shannon-Wiener diversity index formula (Anne, 1988):

$$
H^{\prime}=-\sum_{i=1}^{s} p_{i} \ln p_{i}
$$

where $\mathrm{H}^{\prime}$ = Shannon-Wiener's index of species diversity; $\mathrm{p}_{\mathrm{i}}=\mathrm{n}_{\mathrm{i}} / \mathrm{N}, \mathrm{n}_{\mathrm{i}}=$ Number of individuals of a $\mathrm{i}^{\text {th }}$ species; $\mathrm{N}=$ Number of individuals summed over all species; $\ln =$ Natural $\log$.

Results and Discussion: A total of 672 individuals of 21 species of Odonata belonging to 16 genera, four families and two suborders were collected from the six selected provenances of sandal during the survey periods. Among the 21 species, Marayoor recorded 20 species, Bengaluru 17 species, Javadis 16 species, Thangali 12 species, Mandagadde 11 species and Chitteri eight species (Table 2). On the basis of number of identified species, Libellulidae was the most dominant family represented by 15 species, followed by family Coenagrionidae by four species and Euphaeidae and Gomphidae represented by one species each. Many earlier workers reported the dominance of family Libellulidae in the Indian sub continent. Kumar \& Mitra (1998) recorded 42 species from Sahstradhara, Dehra Dun, out of which 18 species were represented by the family Libellulidae. Prasad (2002) recorded 162 species from western Himalaya, out of which 42 species were represented by the family Libellulidae. Kumar (2002) recorded 109 species in Jharkhand state, out of which 40 species were represented by the family Libellulidae. Vashishth et al. (2002) recorded 17 species in Rajaji National Park, out of which nine species were represented by the family Libellulidae. Kandibane et al. (2005) recorded 12 species of odonates in an irrigated rice field of Madurai, out of which seven species were represented by the family Libellulidae. Emiliyamma (2005) recorded 31 species of odonates in the Kottayam district, out of which 18 species were represented by the family Libellulidae \& Emiliyamma et al. (2005) recorded 137 species of odonates from Kerala, out of which 56 species were represented by the family Libellulidae.

In terms of number of individuals Bengaluru Sandal provenance recorded 202 individuals followed by Marayoor (134), Javadis (120), Mandagadde (87), Thangali (84) and Chitteri (45) (Table 3). In terms of number of individuals, the family Libellulidae recorded 539, Coenagrionidae 123, Gomphidae seven and Euphaeidae three specimens. This was in accordance with the results of Shelton \& Edward (1983) who stated that common species had more individuals than rare species and had the ability to survive in existing environmental conditions. Hurd et al. (1971) stated that the abundance of one group of insects is to have little effect on the other species in a stable ecosystem.

The species diversity of Odonata calculated by using Shannon-Weiner diversity index was the highest in Javadis sandal provenance being 2.440 and the least in Chitteri sandal provenance being 1.743 (Table 4). The high species diversity in Javadis sandal provenance may be attributed to its diversified nature due to the presence of many water bodies including rice fields. This is in agreement with the view of MacArthor (1965) who stated that the adjustment in species abundance is more in diversified ecosystem. The studies on the Odonata diversity by Kumar \& Mitra (1998); Prasad (2002); Kumar (2002); Vashishth et al. (2002); Kandibane et al. (2005) represented the Odonata diversity on the basis of the total number of odonate species. Vashishth et al. (2002) also 
Table 1. Details of sandal provenances selected for the study

\begin{tabular}{|c|c|c|c|c|c|c|}
\hline Sandal provenanaces & Forest Division \& State & $\begin{array}{l}\text { Latitude \& } \\
\text { Longitude }\end{array}$ & $\begin{array}{l}\text { Altitude } \\
(\mathrm{m})\end{array}$ & $\begin{array}{l}\text { Mean annual } \\
\text { rainfall }(\mathrm{mm})\end{array}$ & $\begin{array}{l}\text { Temp-Max/ } \\
\text { Min }\left({ }^{\circ} \mathrm{C}\right)\end{array}$ & Soil Type \\
\hline Bengaluru & Bengaluru, Karnataka & $12^{0} 58^{\prime} \mathrm{N} 77^{\circ} 38^{\prime} \mathrm{E}$ & 1000 & 850 & $36.8 / 12.2$ & Red loam \\
\hline Thangali & Chikkamagaluru, Karnataka & $13^{\circ} 40^{\prime} \mathrm{N} 76^{\circ} 00^{\prime} \mathrm{E}$ & 766 & 1500 & $44.0 / 10.5$ & Red loam \& alluvium \\
\hline Mandagadde & Shivamogge, Karnataka & $13^{\circ} 9^{\prime} \mathrm{N} 75^{\circ} 40^{\prime} \mathrm{E}$ & 650 & 2000 & $38.1 / 13.0$ & Red loam \\
\hline Chitteri & Harur, Tamil Nadu & $12^{\circ} 0^{\prime} \mathrm{N} 78^{\circ} 6^{\prime} \mathrm{E}$ & 1050 & 1000 & $35.2 / 8.2$ & Red sandy loam \\
\hline Javadis (Kavalur) & Tirupattur, Tamil Nadu & $12^{\circ} 3^{\prime} \mathrm{N} 78^{0} 7^{\prime} \mathrm{E}$ & 930 & 1200 & $38.0 / 12.4$ & Red loam \\
\hline Marayoor & Munnar, Kerala & $10^{0} 1^{\prime} \mathrm{N} 77^{0} 1^{\prime} \mathrm{E}$ & 1000 & 1450 & $36.0 / 10.0$ & Black clay \\
\hline
\end{tabular}

Table 2. Taxonomic composition, presence and total number of individual of 21 species of Odonata recorded in six selected provenances of sandal during 2004-05

\begin{tabular}{|c|c|c|c|c|c|c|c|}
\hline & & & & Sandal prove & es & & \\
\hline & & & Karnataka & & & & Kerala \\
\hline & & Bengaluru & Thangali & Mandagadde & Javadis & Chitteri & Marayoor \\
\hline 1 & Ceriagrion cerinorubellum (Brauer) & 4 & - & - & 2 & - & 1 \\
\hline 2 & Ceriagrion coromandelianum (Fabricius) & 14 & 6 & 8 & 12 & 4 & 11 \\
\hline 3 & Pseudagrion r. rubriceps Selys & 11 & 4 & 5 & 9 & 2 & 4 \\
\hline 4 & Ischnura a. aurora (Brauer) & 8 & 4 & 4 & 6 & 2 & 2 \\
\hline 5 & Anisopleura comes Hagen & - & - & 2 & 1 & - & - \\
\hline 6 & Ictinogomphus rapax (Rambur) & 2 & - & - & 4 & - & 1 \\
\hline 7 & Orthetrum pruinosum neglectum (Rambur) & 12 & 8 & 4 & 7 & 2 & 5 \\
\hline 8 & O. s. sabina (Drury) & 8 & 2 & - & - & - & 2 \\
\hline 9 & O. $t$. triangulare (Selys) & - & - & 2 & 4 & - & 2 \\
\hline 10 & Acisoma p. panorpoides Rambur & 9 & 2 & - & 2 & - & 1 \\
\hline 11 & Brachythemis contaminata (Fabricius) & 2 & - & 5 & - & - & 4 \\
\hline 12 & Crocothemis s. servilia (Drury) & 12 & 9 & 4 & 5 & - & 7 \\
\hline 13 & Diplacodes trivalis (Rambur) & 11 & 7 & - & 12 & 6 & 6 \\
\hline 14 & Neurothemis $t$. tullia (Drury) & - & - & 2 & 6 & - & 1 \\
\hline 15 & Trithemis aurora (Burmeister) & 4 & - & - & 9 & 11 & 2 \\
\hline 16 & T. festiva (Rambur) & 4 & - & - & 2 & - & 2 \\
\hline 17 & T. pallidinervis (Kirby) & - & 2 & - & - & - & 5 \\
\hline 18 & Palpopleura s. sexmaculata (Fabricius) & 6 & 4 & - & - & - & 2 \\
\hline 19 & Tramea virginia (Rambur) & 3 & - & - & 6 & - & 1 \\
\hline 20 & Pantala flavescens (Fabricius) & 78 & 32 & 45 & 33 & 16 & 64 \\
\hline 21 & Tholymis tillarga (Fabricius) & 14 & 4 & 6 & - & 2 & 11 \\
\hline & Total & 202 & 84 & 87 & 120 & 45 & 134 \\
\hline
\end{tabular}

calculated the species diversity of odonate by using ShannonWiener diversity index in Motichur forest range of Rajaji National Park which was 3.371 and 2.759 during 1997-98 and 1998-99 respectively, while Kandibane et al. (2005) used Jaccord coefficient index of similarity to study the diversity of odonate between weeded and partially weeded rice ecosystems of Madurai showed greater diversity 0.50 and the diversity of both dragonfly and damselfly did not show variations between the rice varieties. The study confirmed the existence of a wide diversity of odonate in the selected provenances of sandal and this might be playing a potential role in keeping the insect pest population under control.

\section{REFERENCES}

Anne, E.M. (1988). Ecological Diversity and measurement, University press, Cambridge, 179pp.
Emiliyamma, K.G. (2005). On the Odonata (Insecta) fauna of Kottayam district, Kerala, India. Zoos' Print Journal 20(12): $2108-2110$.

Emiliyamma, K.G., C. Radhakrishnan \& J.P. Muhamed (2005). Pictorial Handbook On - Common Dragonflies and Damselflies of Kerala. Published Director, Zoological Survey of India, 67pp.

Fraser, F.C. (1933). The Fauna of British India including Ceylon and Burma, Odonata, Vol. I. Taylor and Francis Ltd., London, 423pp.

Fraser, F.C. (1934). The Fauna of British India including Ceylon and Burma, Odonata, Vol. II. Taylor and Francis Ltd., London, 398pp.

Fraser, F.C. (1936). The Fauna of British India including Ceylon and Burma, Odonata, Vol. III. Taylor and Francis Ltd., London, $461 \mathrm{pp}$.

Gunathilagaraj, K., R.P. Soundarajan, N. Chitra \& M. Swamiappan (1999). Odonata in the rice fields of Coimbatore. Zoos' Print Journal 14(6): 43-44.

Hurd, L.E., M.V. Mellinger, I.L. Wolf \& S.J. Mc Naughton (1971). Stability and diversity in three trophic levels in terrestrial successional ecosystem. Science 173: 1134-1136.

Kandibane, M., S. Raguraman \& N. Ganapathy (2005). Relative abundance and diversity of Odonata in an irrigated rice field of Madurai, 
Table 4. Species diversity of Odonata in six selected provenances of sandal

\begin{tabular}{ll}
\hline Sandal provenances & Species diversity $\left(\mathbf{H}^{\prime}\right)$ \\
\hline Bengaluru & 2.277 \\
Thangali & 2.077 \\
Mandagadde & 1.762 \\
Chitteri & 1.743 \\
Javadis & 2.440 \\
Marayoor & 2.080 \\
\hline
\end{tabular}

Tamil Nadu. Zoos' Print Journal 20(11): 2051-2052.

Kumar, A. (2002). Odonata diversity in Jharkhand state with special reference to niche specialization in their larval forms, pp.297-314. In: Kumar, A. (ed.). Current Trends in Odonatology. Daya Publishing House, Delhi (India), 377pp.

MacArthor, R.H. (1965). Pattern of species diversity. Biological Review 40: 5 10-533.

Prasad, M. (1987). A note on the Odonata from South India. Fraseria 12: 50

Prasad, M. (2002). Odonata diversity in Western Himalaya, India, pp.221254. In Kumar, A. (ed.). Current Trends in Odonatology. Daya Publishing House, Delhi (India), 377pp.

Prasad, M. \& R.K. Varshney (1995). A checklist of the Odonata of India including data on larval studies. Oriental Insects 29: 385-428.

Shelton, M.D. \& C.R. Edwards (1983). Effects of weeds on the diversity and abundance of insects in soybeans. Environmental Entomology 12 : 296-299.

Subramanian, K.A. (2002). Nature watch when dragons fly. Resonance, Journal of Science Education 7(10): 69-78.

Tsuda, S. (1991). A distributional list of world Odonata. Osaka, 362pp. Vashishth, N., P.C. Joshi \& A. Singh (2002). Odonata community dynamics in Rajaji National Park, India. Fraseria 7: 21-25.

\section{AcKnowledgements}

The authors are grateful to Dr. K.S. Shashidhar, the Director, Sri. S.C. Gairola, the Coordiantor (Research) and Dr. O.K. Remadevi, the Head, Wood Biodegradation Division, Institute of Wood Science and Technology, Bangalore for the facilities provided. Thanks are due to Prof. C.A. Viraktamath, Department of Entomology, University of Agricultural Sciences, GKVK, Bangalore for his valuable comments. Financial assistance provided by the Ministry of Environment and Forests, Govt. of India for conducting this research work, is also gratefully acknowledged.

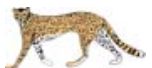

\section{NEW LARVAL FOOD PLANTS OF PRECIS (JUNONIA) ALMANA L. AND LEPTOSIA NINA FABR. (LEPIDOPTERA)}

\section{K. Anoop ${ }^{1}$ and Mohammed Jafer Palot ${ }^{2}$}

${ }^{1}$ Every Child A Scientist Programme, M.S. Swaminathan Research Foundation, CAbC, Kalpetta, Wyanad, Kerala, India ${ }^{2}$ Zoological Survey of India, Western Ghats Field Research Station, Annihall Road, Kozhikode, Kerala, 673002, India

Email: ${ }^{1}$ anoop_mssrfb@yahoo.com; ${ }^{2}$ jaferpalot@gmail.com

Observations on new records of host for two species of butterflies, the Peacock Pansy Precis (Junonia) almana Linnaeus and the Psyche Leptosia nina (Fabricius) are presented here.

While working on the butterflies of the Wyanad hills of the southern Western Ghats, on 12 May 2005, we came across a larva feeding on the foliage of Cleome monophilla (locally known as Vaal kaduku due to its long mustard like seed pods), near a paddy field at Kunnamangalam vayal, about $4 \mathrm{~km}$ from Meppady. This plant is common along the edges of the road and also found among the paddy fields. The larva pupated two days later. The pupa was black and white in colour and the adult emerged after six days. It was later identified as the Peacock Pansy Precis almana. Caterpillars of the Peacock Pansy are known to feed on Acanthus sp., Barleria sp., Gloxinia sp., Hygrophila auriculata, Phyla nodiflora of the Families Acanthaceae, Gesneriaceae and Verbenaceae (Wynter-Blyth, 1957; Kunte, 2000; Palot et al., 2003). In the present communication, we are reporting Cleome monophilla (Family: Capparidaceae) as a host plant of the Peacock Pansy for the first time.

The Psyche Leptosia nina is one of the smallest butterflies in the family Pieridae. This species is widespread and active almost throughout the year. On 13 February 2006, while observing the butterflies of the MSSRF garden, Puthurvayal, Kalpetta, Wyanad district we observed a Psyche butterfly laying eggs on the underside of the Cardamine hirsute (Brassicaceae) plant. After three days it pupated. The pupa was green in colour with yellowish-brown spots. On 20 February 2006, after a gap of four days adult emerged out of the pupa.

The larvae of the Psyche butterfly Leptosia nina are known to feed on Capparis rheedii, C. spinosa, C. zeylanica, Cleome viscose and Crateva adamsonii, all belonging to the family Capparaceae (Wynter-Blyth, 1957; Kunte, 2000; Palot et al., 2003). The present record of Cardamine hirsute (Family: Brassicaceae) is a new addition to the list of larval food plants of the Psyche butterfly.

\section{REFERENCES}

Kunte, K. (2000). Butterflies of Peninsular India. University Press (India) Limited, Hyderabad, 254pp.

Palot, M.J., V.C. Balakrishnan \& B. Kambrath (2003). Keralathile Chialbhangal (Butterflies of Kerala). Malabar Natural History Society 240pp. Wynter-Blyth, M.A. (1957). Butterflies of Indian Region. Bombay Natural History Society, Bombay, 532pp. 